\title{
FROM TEARS TO POISON: \\ RAGUSAN DEALINGS WITH THE ENEMIES FROM THE OTTOMAN NEIGHBOURHOOD*
}

\author{
Vesna Miović \\ Croatian Academy of Sciences and Arts, Dubrovnik
}

\begin{abstract}
It was in the mid-fifteenth century that the Ragusans started paying tribute to the Ottoman sultan, which, by the early 1480 s, stabilised at an annual sum of 12,500 gold ducats. In return the Ottoman Empire was to act as protector of the Dubrovnik Republic. Ragusan merchants could trade safely throughout Ottoman territory. Twice underlined in the terms of the so-called Ragusan ahdname is that no person from the Ottoman Empire may act to the harm of the Dubrovnik Republic. However, the Republic was threathened by many, from Bosnian beylerbeys to the brigands raiding the Empire territory, while the Ottoman authorities remained reluctant and fairly inefficient in the implementation of the promised protection. This paper aims to elucidate the methods of self-protection developed by the Dubrovnik authorities in the given circumstances.
\end{abstract}

\begin{abstract}
Abaza Mehmed Pasha assumed the position of Bosnian beylerbey in 1629. To mark this occasion, Dubrovnik Republic sent its ambassadors to Sarajevo to express their best wishes and present him with the gifts, during which he left an impression of being a cordial, gentle and pleasant dignitary. However, things soon proved contrary, as the pasha sided with Venice. He blocked the caravan route to Dubrovnik and channelled it towards Split. By giving priority to Venice, he took all the possible steps to ban the Ragusans from selling salt to Ottoman subjects in Gabela. Among other things, he ordered the imprisonment of the Ragusan nobleman appointed to oversee the sale of salt there. ${ }^{1}$ An even bigger blow followed in 1631 . The Venetians
\end{abstract}

The research for this article has been supported by a grant from Croatian Science Foundation (no. 5527).

1 From the 1520s onwards, in Gabela the Ragusans had a monopoly on the sale of salt to Ottoman subjects. In the beginning, they split the profit by half with the Ottomans, only to change it later to two thirds in their favour, justfying the reduction by large transport costs. When the Ottoman subjects arrived to purchase salt, they would bring various goods for sale with them. In fact, Gabela was an entrepôt under Ragusan control, overseen by a Ragusan nobleman, the so-called venditore di sale. From the end of the sixteenth and early seventeenth century the Venetians began to undermine Ragusan salt monopoly in Gabela. On several occasions they obtained fermans authorising them to sell salt together with the Ragusans. Ragusan ambassadors, however, managed to annul Ottoman fermans and obtain their own, which they would promptly deliver to Bosnian administrators with their own request for intervention (State Archive in Dubrovnik /hereafter cited as SAD/, Diplomata et Acta / hereafter cited as DA/, 7/2.1, Sultans'documents, 
landed on Lokrum, island in the immediate vicinity of Dubrovnik, ${ }^{2}$ of which the pasha refused to inform the Porte. At the same time, he set off for Herceg Novi via the Ragusan territory of Konavle, and made no effort to prevent his soldiers from plundering the villages along the way. He seized two noblemen, ambassadors who greeted him on the border, took them to Herceg Novi, threatening to behead them unless they paid ransom. He freed them upon receiving 10,000 thalers. The ambassadors returned to Dubrovnik in a severly exhausted state. ${ }^{3}$

Dubrovnik authorities thus decided to take all possible actions to remove Abaza Mehmed Pasha from their neighbourhood. Luka Menze and Marin Cerva, ambassadors who delivered tribute to the sultan in Istanbul, were ordered to intervene with all ten viziers of the imperial divan and other influential persons at the Porte. Menze and Cerva acted as instructed, and complained bitterly about the violent conduct of Abaza Mehmed Pasha and his allies the Venetians, claiming that if the Porte failed to take immediate actions, Dubrovnik state would inevitably collapse. While writing to the government about their actions, the ambassadors particularly emphasised that, "as is customary in such difficult situations", they sobbed and cried. ${ }^{4}$ The Bosnian-born kaymakam of the grand vizier consoled them in their mother tongue by saying that Abaza Mehmed Pasha would pay for everything he had done to them. Equal consolation worded in the native Bosnian language the Ragusans received from grand defterdar: "Fear not, we shall have him removed". The viziers listened patiently to the complaints submitted by Menze and Cerva, sympathising with them as they wept. They promised prompt resolution of the Ragusan problems with Abaza Mehmed and the Venetians, determined in their intent to protect the sultan's loyal tributaries from further harassment. ${ }^{5}$

The news that Murat Pasha, born in Čajniče in Bosnia and kaymakam's favourite, would be appointed new beylerbey of Bosnia soon reached Dubrovnik. Murat Pasha looked for Menze and Cerva, sat between them, took them by the hand, and uttered joyfully: "We are neighbours, we speak the same language". He warned them that Abaza Mehmed had powerful allies at the Porte, and that they should continue with their tearful presentations of his ill actions. The ambassadors responded that the Ragusans always prayed God for Bosnia to be governed by

vol. 8, no. 354; vol. 11 , no. 543; vol. 12 , no. 579 , 588, 589; vol. 13 , no. 603 , 604, 606, 610, 621; vol. 14 , no. 657,658 ; vol. 16 , no. 756,757 ; vol. 18 , no. 878,881 ; vol. sv. 19 , br. 936 , 947 ; vol. 22 , no 1034, 1036; vol. 30, no. 1234).

2 For a more extensive account on Venetian pretensions to the island of Lokrum see: Antun Vučetić, Lokrum i odnošaji Dubrovnika sa Mletcima u XVII vieku iz izvještaja poslanika M. Sorga (Split: Štamparija A. Zannoni, M. Snidarčić, 1889).

3 Radovan Samardžić, Veliki vek Dubrovnika (Beograd: Prosveta, 1983), 86-91, 94. SAD, Lettere di Levante (hereafter cited as: Let. Lev.), series 27.1, vol. 45, ff. 188, 188v, 191v-194v

4 ...in somma cominciam a singultare, e piangere come si conveniva in questi frangenti... $\left(D A, 17^{\text {th }}\right.$ century, vol. 1823, no. 1).

$5 D A, 17^{\text {th }}$ century, vol. 1823 , no 1 . 
prudent local men. ${ }^{6}$ Abaza Mehmed Pasha was soon instructed by the Porte to leave Bosnia. The new Bosnian beylerbey, Ragusan friend Murat Pasha, set out for Sarajevo in the middle of October 1631.7

The exact amounts of money that the Ragusans gave to Ottoman dignitaries in order to bend them against Abaza Mehmed Pasha and in their favour are not known. In addition, the mentioned pasha was the reason why they abandoned a very convenient method of calculating tribute. Apparently, at that time they did not pay tribute in gold ducats, but in silver coins. The real exchange rate in the Empire was two silver coins to one gold ducat, while the Ragusans kept to the exchange rate of one and a half silver coin for a gold ducat, as regulated by the Ottoman state. The Porte viziers were not happy to receive tribute in silver, which the Ragusans successfully accounted for by the deficit of gold ducats. In 1631 the defterdar was literally furious when they delivered 18,750 thalers instead of 12,500 ducats. Kaymakam warned the tribute ambassadors that they might have to disburse 25,000 unless they wished to lose defterdar's favour. As the deposition of Abaza Mehmed Pasha was of essential importance for the Dubrovnik Republic, the ambassadors wasted no time and started collecting the necessary sum by borrowing money from various sources. ${ }^{8}$

Judging by the advice given by Murat Pasha, the tears shed by Ragusan ambassadors played a crucial role in the dismissal of Abaza Mehmed Pasha. Apparently, everyone was aware of how efficient tears could be. As professionals in their duty, Ragusan ambassadors would resort to this act whenever instructed by the government, whereby the instructions were known to be most detailed at times. ${ }^{9}$

6 Questo Signore il primo ci truovo nel anticamara di Sua Eccelenza e sedette in mezzo di Ser Luca, e a me, ci piglio per le mani, e cominci a ralegrarsi con noi, dicendoci noi tutto siamo vicini consie, parliam una lingua, l'Abas Pasa ci perseguito, sicome fa da per tutto, sono venute molte querele, e di Herzegovina, e di Bosna contro lui, ma perche tiene potenti amici in questa corte, se voi non attenderete, e piangerete da per tutto dificilmente sara mutato, e pero io come amico vostro, vi esorto che hormai vi risolvete di dir al aperta li sua misfati, e le sua scagare, perche se voi attenderete di levarlo io attendero di sucedergli al suo loco, e saro vostro amico (DA, $17^{\text {th }}$ century, vol. 1823, no. 1$)$. $D A, 17^{\text {th }}$ century, vol. 1823 , no. 3 .

8 American silver caused quite a stir on the financial market. A generally steady ratio between silver and gold in both Dubrovnik and the Ottoman Empire (1:1.5) began to change. Due to the deficiency in gold coins, in the period between 1615 and 1635 the value of sequin increased by $91 \%$ in the Empire, and by only $18 \%$ in Dubrovnik. The Ragusans took advantage of this ideal opportunity. Since the 1620 s, tribute ambassadors secretly carried gold ducats with them, and en route to Istanbul exchanged them into silver coins according to real exchange rate. Thus the tribute they delivered in Istanbul was disbursed at an artificially maintained exchange rate. As the defterdar's pressure discouraged them from making further payments in thalers, from 1632 the tribute was paid in gold ducats (Vesna Miović, Dubrovačka diplomacija u Istambulu (Zagreb - Dubrovnik: HAZU Zavod za povijesne znanosti u Dubrovniku, 2003), 180-182).

9 Enecessario, che in questo colloquio vi comporriate in maniera tale che la lingua realmente esprima quell'affanno che sente il cuore, e che gli occhi non manchino di attestare con copiose lacrime la verita di cuore, e della linqua. Onde fra l'insistenza delle vostre umiliazioni, e ragioni, e nel fervore delle preghiere vi buttarete un dietro l'altro a piedi di Sua Altezza con pianto, e singhiozzi implorarete il suo patrocinio, nel quale, direte, esser unicamente riposta tutta la nostra maggior speranza ... (an 
It appears that Bosnian beylerbeys rarely went to Herceg Novi, unlike the sancakbeys of the Herzegovinian sancak. Upon installation, every new sancakbey would inspect his province, and the route to Herceg Novi led through the Dubrovnik territory of Konavle. This was an extremely awkward situation for the Ragusans, as they always dreaded potential skirmishes and conflicts between sancakbey's soldiers and the locals of Konavle. For this reason they introduced a protocol which was to keep the situation under control, to a certain extent at least. Upon the news that the sancakbey, usually accompanied by one to two hundred soldiers, was approaching the border, two noblemen were dispatched to greet him. The noblemen would escort the sancakbey through Konavle, treated him to a luncheon at the monastery of St Blaise in Pridvorje, and presented him with some gifts. In Herceg Novi they remained with him for eight days, during which they flattered him excessively and recommended Ragusan merchants, subjects and Ragusan business affairs in general. ${ }^{10}$

Following the disaster with Abaza Mehmed Pasha, Ragusan ambassadors at the Porte managed to obtain a ferman by which Bosnian beylerbeys en route to Herceg Novi were not allowed to set foot in Konavle, ${ }^{11}$ the same ban being requested with regard to the sancakbeys of Herzegovina. Contrarily, Konavle was plundered again in 1641. Herzegovinian sancakbey Şahin Pasha, like Abaza Mehmed, first ordered the seizure of the Ragusan nobleman responsible for the sale of salt in Gabela. He threatened to have him impaled only to be remembered as a person who punished a Ragusan nobleman in such a horrific way. In June 1641 he set off for Herceg Novi. Defence of the most vulnerable villages in Konavle was soon organised. Although the soldiers of Şahin Pasha plundered and destroyed the villages on the way, harassing their inhabitants who had not been duly evacuated, an open conflict never took place. ${ }^{12}$

example from 1721. Let. Lev. vol. 71, f. 17). On emotions in diplomatic dealings of Dubrovnik and elsewhere in Europe: Filippo de Vivo, "Archives of Speech: Recording Diplomats Negotiation in Late Medieval and Early Modern Italy," European History Quarterly 46/3 (2016): 519-544. Isabella Lazzarini, "Argument and Emotion in Italian Diplomacy in the Early Fifteenth Century: the Case of Rinaldo degli Albizzi (Florence, 1399-1439)," in: The Languages of Political Society, ed. A. Gamberini, J.-P. Genet (Roma: Viella, 2011), 339-369.Vesna Miović, "Diplomatic Relations Between the Ottoman Empire and the Republic of Dubrovnik," in: The European Tributary States of the Ottoman Empire in the Sixteenth and Seventeenth Centuries, ed. Gábor Kármán, Lovro Kunčević (Leiden-Boston: Brill, 2013), 205-198. Valentina Zovko, "The First Ambassadors from Dubrovnik at the Sublime Porte (1430/31)," in: Turkey \& Romania; A History of Partnership and Collaboration in the Balkans, ed. Florentina Nitu, Cosmin Ionita, Metin Ünver, Özgür Kolçak, Hacer Topaktaş (Istanbul: Türk Dünyası Belediyeler Birliği, 2016), 43-47.

10 Vesna Miović, "Beylerbey of Bosnia and Sancakbey of Herzegovina in the Diplomacy of the Dubrovnik Republic," Dubrovnik Annals 9 (2005): 46-48.

11 DA, 7/2.1, Sultans' documents, vol. 18, no. 884 .

12 Let. Lev. vol. 48, ff. 23-24, 26, 26v, 28, 28v, 38v-41, 45v-47, 49v, 50v-52v, 66v-80v, 83, 84v. Vuk Vinaver, "Bosna i Dubrovnik 1595-1645," Godišnjak Druśtva istoričara Bosne i Hercegovine 13 (1962): 218-220. 
This time it was not necessary for the ambassadors to resort to tears in order to request the removal of Şahin Pasha from the viziers at the Porte. The Ragusans had another solution at their disposal, compatriot Frano Crasso, physician who treated the Grand Vizier Kemankeş Kara Mustafa Pasha. ${ }^{13}$ Crasso claimed that his master was very fond of him and was therefore certain that the dismissal of Şahin Pasha would be a trifle matter. ${ }^{14}$ In September he already reported that the raving tyrant Şahin Pasha had been removed from the post of the Herzegovinian sancakbey, to be replaced by Ahmed Pasha, a man worthy, reasonable and inclined towards the Republic of Dubrovnik. ${ }^{15}$

The Vlachs from the Herzegovinian neighbourhood and the Montenegrins constantly raided the villages along the Republic border. From the 1640s onwards, young aghas of Herceg Novi also represented great threat. Some of the prominent men of Herceg Novi were appalled by the misdeeds committed by their fellowcitizens in the rural areas of Dubrovnik. Yet, these peaceful aghas did not have the power to protect Ragusans whom they considered friends. Thus from the Ragusan standpoint it seemed as though the whole of Herceg Novi conspired against the Republic. The situation deteriorated considerably in the early days of the War of Candia in 1645. Alaga (Ali Agha) Šabanović, Omer Agha Begzadić, Ali Agha Kurdagić, Ishak Ćehajić and many others, along with the brigands of Risan and Trebinje, and the Vlachs and Montenegrins all left their own stamp on the war era. ${ }^{16}$

Alaga Šabanović and Omer Agha Begazadić, outlaws and brigands from Herceg Novi, were the worst nightmare of the Ragusans in the 1650s. They attacked merchant caravans, raided and pillaged the villages along the border, killed, raped and abducted people to slavery. ${ }^{17}$ They claimed that in this way they revenged on the Ragusans, because the haiducs on their way to Herzegovina were not prevented from passing through Dubrovnik territory and because Ragusan subjects collaborated with them. In true fact, Dubrovnik villages were also raided by haiducs in the service of Venice. The Ragusans confronted haiducs as much as they could,

13 DA, $17^{\text {th }}$ century, vol. 1861, no. 1-8. Let. Lev vol. 48, ff. 49v, 90-91v, 98-99v.

14 Let. Lev. vol. 48, ff. 101v, 102.

15 ... finalmente Scah Pascia sabbato ali 21 di questo fu deposto dal governo di Herzegovina et investito di qualla carica Abmet Pascia, che fu suo predecesore. Onde in un istesso tempo s'e rimosso da quella vicinanza un' inquieto, furioso, e mall' affetto tirano, e messosi in cambio un merituito, prudente et assai ben inchinato a ogni sodisfattione di Vostre Eccellenze... (DA, 17 ${ }^{\text {th }}$ century, vol. 1861, no. 9).

16 On the relations between Dubrovnik and Herceg Novi in the seventeenth century see: Samardžić, Veliki vek Dubrovnika, 126-198. Radovan Samardžić, "Odnosi Bosne i Dubrovnika od 1656 do 1662," Godišnjak Istoriskog društva Bosne i Hercegovine 8 (1956): 87-173. Bogumil Hrabak, “'Zlići' iz Herceg-Novog i zulumćarenje na uštrb dubrovačke trgovine 1600-1667. godine," Boka 12 (1980): 81-119.

17 Samardžić, Veliki vek Dubrovnika, 128, 129, 136-147, 153, 156, 160, 161, 165, 173, 182-185. 
and always punished the local villagers, in Konavle mainly, for collaborating with haiducs. ${ }^{18}$ In sum, during the entire War of Candia the Republic of Dubrovnik paid a very high price for its neutrality. Through haiducs they were actually attacked by Venice. On the other hand, Dubrovnik also suffered the attacks of Herceg Novi outlaws under the pretext of the revenge for the haiduc pillages of Herzegovina. ${ }^{19}$

Seeking Ottoman help against Begzadić and Šabanović, the Ragusans resorted to a well-devised strategy. First, they would report the crimes to the kadi, in this case that of Herceg Novi, followed by a request for the kadı to write a report according to their suggestions, and it was not rare that they even provided him with a draft of the court report they themselves had composed..$^{20}$ In lieu of a customary monetary gift, ${ }^{21}$ the kad1 would write down a report on the brigand misdeeds according to the Ragusan wording, and sealed it with his own seal. On the basis of these kadı reports, Ragusan ambassadors at the Porte would petition for particular fermans.

Five fermans issued in the period 1651-8 have been preserved, by which the sultan demanded from the Bosnian beylerbey to bring Alaga Šabanović and Omer Agha Begzadić to justice. ${ }^{22}$ Shortly upon the ferman's issue, Ragusan authorities would dispatch their envoys to the beylerbey with an instruction to overstate in their descriptions the scale of the criminal actions of Šabanović and Begzadić ${ }^{23}$ after which they would offer money for their heads. In 1657 Ragusans were willing to offer 4,000 thalers for Begazadićs head and 2,000 thalers for that of Šabanović. In the early days of 1659 , they ordered the state treasurers to disburse 4,000 thalers to a certain Jusuf-efendi, which he would keep with him and deliver to Seidi Ahmed Pasha if he had Šabanović eliminated. ${ }^{24}$

However, to many Herzegovinians, and especially to the people of Herceg Novi, Šabanović and Begzadić were Candian War heroes, and they offered them help and hiding place. Thus the efforts of some Bosnian beylerbeys to capture them remained fruitless. Other beylerbeys, however, did not even show the slightest interest in bringing them to justice, among whom Seidi Ahmed Pasha may be singled out, a tyrant of the Dubrovnik Republic and the Bosnian eyalet alike.

18 Vesna Miović-Perić, Na razmedu; osmansko-dubrovačka granica 1667-1806 (Dubrovnik: Zavod za povijesne znanosti HAZU u Dubrovniku, 1997), 191-197.

$19 D A 17^{\text {th }}$ century, vol. 1823, no. 3. Samardžić, Veliki vek Dubrovnika, 117-125.

20 The drafts of kadıs' reports composed by Dubrovnik dragomans: SAD, Acta Turcarum (hereafter cited as: Acta Turc.), series 75, no. 1389, 1406, 1417, 1419, 1420, 1430, 1431, 1433, 1442, 1448, $1453,1454$.

${ }^{21}$ Let. Lev. vol. 48, f. 185; vol. 56, ff. 38v-39; vol. 60, ff. 37, 37v; vol. 70, f. 15v; vol. 88, f. 7; vol. 106, ff. 27-28v; vol. 110, f. 107-108.

$22 D A, 7 / 2.1$, Sultans' documents, vol. 24, no. 1080, 1099, 1100, 1129; vol. 27, no. 1162.

23 Let. Lev. vol. 56, f. 143.

24 SAD, Secreta Rogatorum (hereafter cited as: Secr. Rog.), series 4, vol. 4, ff. 241, 271; vol. 5, f. 1. 
In the summer of 1657 a ferman was issued for the attack on Kotor, with an aim to destroy Venetian rule in Boka, along with the Boka-based haiduc nest. Seydi Ahmed Pasha showed reluctance with regard to this attack, and at the same time did not wish to express openly his insubordination to the sultan. He still headed the army towards Boka, though at a very slow pace. Ragusan envoys intersected him twice and exhibited the ferman by which Bosnian beylerbeys and Herzegovinian sancakbeys were not allowed to pass through Konavle en route to Herceg Novi, offered him money, presents and bags of food for the army. In any case, the pasha penetrated the territory with 1,500 soldiers who pillaged and raided the area for three days. One year later, the pasha spread a rumour that the Ragusans were collaborating with haiducs and incited his men to revenge attacks against Dubrovnik, Alaga Šabanović being among them. They raided the villages of Župa dubrovačka, leaving only "stones unturned". 25

Although he had a handful of fermans on the basis of which he could bring Alaga Šabanović to justice, Ahmed Pasha drank wine with him in Sarajevo in 1659, organised him a grand tour of the city, and appointed him as sancakbey of Krka. The pasha was on good terms with all Herceg Novi outlaws, except for Omer Agha Begzadić, because the former deposed him from the commanding position of the Herceg Novi military guard. Begzadić was killed in 1658 in a conflict with pasha's soldiers. Although his death had no connection with the misdeeds he had committed on Dubrovnik territory, the pasha managed to cash a price for his head from the Ragusans amounting to 2,000 thalers. ${ }^{26}$

The complaints against Seydi Ahmed Pasha's violent conduct on behalf of the representatives of the inhabitants of Bosnia and Herzegovina and Ragusan ambassadors tended to intensify. He was removed in March 1659, thanks largely to the Ragusan actions at the Porte. ${ }^{27}$ A clear illustration of this is a short dialogue between two kapıcıbaşıs from Istanbul and the inhabitants of Prijepolje. When the kapıcıbaşıs commented that Seydi Ahmed Pasha's future was at stake on account of his ill terms with the Ragusans, the people of Prijepolje concluded: "If the gentlemen of Dubrovnik do not put an end to him, no one will". ${ }^{28}$ Ragusan success in eliminating Abaza Mehmed Pasha, Şahin Pasha and Seidi Ahmed Pasha was possibly only the tip of the iceberg, because in 1631, in a quarrel with the Ragusan dragoman Vicko Bratutti regarding the calculation of tribute and Seidi Ahmed Pasha's allegations that the Ragusans collaborated with the uskoks, kaymakam of

\footnotetext{
Let. Lev. vol. 57, ff. 135v, 136.

Let. Lev. vol. 57, f. 135.

27 For more details on Seidi Ahmed Pasha see: Samardžić, Veliki vek Dubrovnika, 147-174.

28 Samardžić, Veliki vek Dubrovnika, 166, 167.
} 
the grand vizier reproached him: "Don't you see how much we have done for you, so many viziers we have dismissed..."

Prompted by a Ragusan monetary reward, Alaga Šabanović was finally seized by Melek Ahmed Pasha, Seidi Ahmed Pasha's successor. He had doubts about Alaga's execution, mostly because his apprehension resulted in a protest among the inhabitants of Herceg Novi, who even offered to pay for his freedom. Yet, Melek Ahmed decided to submit to sultan's order, and by the end of 1659 he had Alaga strangled in prison. ${ }^{30}$

For years the Ragusans worked hard to urge the Ottoman authorities to eliminate Šabanović and Begzadić, yet at the same time they secretly deliberated on how to do it themselves. The names of these rei di mille morti $i^{31}$ were mentioned on several occasions during the secret sessions of the Senate. In 1653 it was decided that Šabanović would be liquidated by poisoning or in some other way at the cost of up to 300 Ragusan ducats. In 1655 the Senate decided to reward the person who would murder Omer Agha Begzadić with 1,000 gold ducats, or even more if necessary. In all likelihood they had poisoning in mind, because one month later surgeon Pavao, son of Andrija, was offered 500 ducats for the preparation of "the said water", that is, poison, and at their disposal they already had the poison they commissioned from Florence. In May 1656, nobleman Marojica Caboga was entrusted with the organisation of Begzadićs liquidation. Elimination of Begzadić together with his entire company by poisoning was mentioned again a month later. ${ }^{32}$ These plans never came to fruition mainly because of the great risk of being disclosed and the eventual revenge on behalf of Herceg Novi.

Mentioned in the minutes of the Senate's secret sessions are also other men from Herceg Novi whom the Ragusans wished to eliminate. In 1641 the senators sentenced to death the Ereizović brothers, ten years later Murat Omerović, Ishak Ćehajić and Mehmed Muho Mirmilović, and they also launched an enquiry about the crimes committed by Glavović and two Kurdagićs, doubtless, with an aim to establish whether they would be liquidated or not. In 1654 they auhorised the rector and the Minor Council to organise the liquidations of the men of Herceg Novi

29 ... non vedete quanto faciamo noi per voi altri, habbiamo fatto masul tanti vesieri, e a Venetiani si ha comandato piu volte, e nel havenire se impara al Signor Ambasiador Veneto, che scriva alla Sua Serenita, che sotto l'disgratia di Sua Maesta non si dia travagli a Signori Ragusei ne per l'ada di Lacroma, ne per le mercantie... (DA, $17^{\text {th }}$ century, vol. 1823, no. 3).

30 Let. Lev. vol. 57, ff. 214v-219. Samardžić, Veliki vek Dubrovnika, 182-185.

31 Let. Lev. vol. 56, f. 143v; vol. 57, f. 216.

32 Secr. Rog. vol. 4, ff. 241, 254, 254v, 255v, 260v, 261. Zdravko Šundrica, “Tajanstvena kutija iz arhiva Dubrovačke Republike," Dubrovački vjesnik, April 11, 1958, 7; April 18, 1958, 7; May 9, 1958, 5; May 17, 1958, 5; May 24, 1958, 7. Zdravko Sundrica, "Poisons and Poisoning in the Republic of Dubrovnik," Dubrovnik Annals 4 (2000): 35. Paolo Preto, I servizi segreti di Venezia (Milano: Il Saggiatore, 1994), 362. 
who on Dubrovnik territory had committed murder or who robbed Ragusan merchants. They suggested liquidation by poisoning, "in some other way" or price on the head of up to 2,000 ducats. ${ }^{33}$

Ali Agha Kurdagić, Ishak Ćehajić and a couple of their men of Herceg Novi in 1655 raided Duba, border village in Konavle, slashed two villagers and threw their bodies to the dogs. In the village of Bani they seized Ivan Karakaš, dragged him off to Herceg Novi and there, together with Alaga Šabanović, had him imapled. Kurdagić pillaged and killed in the village of Stravča. Three archival documents suggest that the punishment for these crimes came from the Ragusan hand. Namely, in February 1655 the senators secretly decided to pardon all the inhabitants of Konavle and Cavtat regardless of the sentence, including that of death, if within the term of six months kill or act as accomplice in the murder of any "Turks" officially enlisted to be eliminated. Two months later Ali Agha Kurdagić was murdered. Many Ottoman subjects claimed that it had taken place on Dubrovnik territory. The Ragusans, however, turned to the kadi of Herceg Novi, who established that Kurdagićs body was found on the territory of Herceg Novi, and in this way made it quite clear that the Ragusans had nothing to do with his murder. ${ }^{34}$

In order to eliminate undesirable persons, the Ragusans formed alliances even with haiducs, with whom they had to cope during the War of Candia. ${ }^{35}$ In the 1660s Ragusan ambassadors persisted on offering money to the sancakbey of Herzegovina for the head of Grujica Vuković, Vlach from Zubci, a robber and outlaw matching the criminal file of Šabanović and Begzadić. ${ }^{36}$ Finally, the count of Konavle met with haiducs and hired them to kill him. ${ }^{37}$

Omer Palikuća from Orahovica near Risan ended his life in 1643 on the gallows in Ploče, eastern suburb of Dubrovnik. He raided the villages in Konavle, but also in the Ottoman Herzegovina, which the Ragusans used as the grounds for their petition for his elimination. The envoy of the Herzegovinian sancakbey captured him in Risan, brought him to Ploče, where he was hanged..$^{38}$ Dubrovnik gallows were located at Danče, in the western suburb of Pile, and the reason why the Ragusans

33 Secr. Rog. vol. 4, ff. 127, 202v, 246v, 247, 251, 257, 264. Šundrica, "Poisons and Poisoning in the Republic of Dubrovnik," 34.

34 Acta Turc. no. 4344, 4349, 4478, 4481. Secr. Rog. vol. 4, f. 251, 251v.

35 For more details on haiduc raids of the Dubrovnik border areas during the War of Candia see: Antun Vučetić, Dubrovnik za Kandijskog rata 1645-1669 iz dopisivanja Republike s M. SorgomBobalijem (Dubrovnik: published by author, 1896).

36 In 1666 Ragusan ambassador offered to the Herzegovinian sancakbey 200 thalers per head of Grujica Vuković, his brother and another six Vlachs from Herzegovina (Let. Lev. vol. 60, ff. 50, 50v). On the prices set on outlaws' heads see also: $D A, 17^{\text {th }}$ century, vol. 1805 a, no. 4.

37 Samardžić, Veliki vek Dubrovnika: 379. Miović-Perić, Na razmedu, 167-177.

38 Let. Lev. sv. 48, f. 148v-149v, 151-152, 176v-180v. SAD, Acta Consilii Rogatorum, series 3, vol. 97, ff. 169v-173v. Acta Turc. vol. B 50, no. 49. 
decided to execute Palikuća at Ploče is quite clear. This suburb was frequented by many Ottoman travellers and merchants, from Bosnia mainly, who kept quarantine in the Lazaretto and traded in Tabor. They witnessed the hanging of Palikuća, because the Ragusan authorities wished to send a message to all those arriving from Bosnia of the fate they awaited should they decide to plunder the villages on the Dubrovnik territory.

Ten years later the Ragusans wished to do the same. In 1656 they seized Mehmed Mirmilović, outlaw from Herceg Novi, threw him into prison and offered 400 ducats to the Herzegovinian sancakbey to have him executed at Ploče. ${ }^{39}$ The proposal obviously failed, as on the next secret session of the Senate an order was issued for a controlled poisoning of Mirmilović, so that he remained on the verge of death when the Ragusans hand him over to the Heceg Novi authorities. The third day of the poisoning operation was crucial. If the physicians established that Mirmilović would not die in prison, a new dose of poison would be administered to him, after which he would be handed over to the authorities of Herceg Novi. Should he be in a feverish state, a sign signifying the oncoming death, an additional dosage of poison would not be necessary. ${ }^{40}$

Much of the mentioned data may be traced in the minutes of the secret sessions of the Senate (Secreta Rogatorum), which contain the most delicate decisions of the Dubrovnik state. Prior to the entry of French troops into the Republic of Dubrovnik, a part of these minutes was destroyed by the Ragusans themselves. ${ }^{41}$ No data from the eighteenth centry have survived, and we may only speculate about the secret decisions passed regarding the Montenegrins, who, at the time, represented the greatest threat to the border villages in Konavle. Such decisions must have been brought, because the Ragusans could not rely on the help of the Ottoman authorities. Ottoman army on several occasions launched sporadic attacks on Montenegro, after which it would withdraw. The Vlachs from Zubci and Kruševica in eastern Herzegovina often collaborated with the Montenegrins, while the local Ottoman authorities in Trebinje made no effort whatsoever to inspect these territories. When in 1770 the Ragusans wrote to Hasan Bey in Trebinje to capture Jovan the Vlach who had stoled a couple of oxen in Konavle, the bey replied that it would not be possible because Jovan lived in "the terrifying territory". ${ }^{42} \mathrm{On}$ the basis of Ragusan complaints supported by numerous kadı reports, ${ }^{43}$ the Porte

\footnotetext{
38 Secr. Rog. vol. 4, f. 263.

40 Secr. Rog. vol. 4, ff. 263-265. Sundrica, "Poisons and Poisoning in the Republic of Dubrovnik," 36, 37.

41 Extant in six registers from $1497 / 1537,1555 / 1569,1604 / 1606,1624 / 1698$.

42 Acta Turc. vol. B 131, no. 41.

43 Acta Turc. no. 4015, 4311, 4393-4395, 4404, 4408, 4423-4425, 4584, 4588.
} 
on several occasions issued fermans against the Montenegrins, ${ }^{44}$ but they proved utterly useless. Therefore, the Ragusans turned to their own resources, dispatched spies to find out what the Montenegrins were plotting, and organised the defence of Konavle. ${ }^{45}$

In 1703, at the Porte Ragusan ambassadors presented a drastic solution to the Montenegrin issue. They hardly mentioned the Montenegrin raids in the Dubrovnik territory, yet placed emphasis on the recent attack of a group of 700 Montenegrins on the villages of eastern Herzegovina. Avenging themselves on the Vlachs who refused to collaborate with them in the attacks on the Dubrovnik area, the Montenegrins burnt down their houses and stole 4,000 head of cattle. The ambassadors petitioned for a ferman to the sancakbey of Skadar to harness Montenegrin violence and to relocate them, for as long as they remained in the neighbourhood, no one would be safe. ${ }^{46}$

Perhaphs under Ragusan influence, the Porte decided to take certain measures three years later. A ferman was issued to the sancakbeys of Herzegovina and Skadar to muster the army, attack the Montenegrins and have them relocated, so that the areas in their vicinity, constantly threatened by them, could finally live in peace. The troops mustered, but Montenegrin representatives managed to persuade the sancakbey of Herzegovina that they would cease the raids and violence, this being officially registered in the kadı register. A couple of Montenegrins surrendered in Skadar as hostages, that is, acting as warrants for their compatriots not to breach the given promise. Yet, only a few days later, the hostages vanished and some one hundred Montenegrins stole 700 head of cattle in the Dubrovnik territory, killed one and abducted four persons. The pasha of Trebinje was preparing for the meeting with the Bosnian beylerbey, and proposed to the Ragusans to send him a letter describing the high price they paid on account of the ill judgement of the Herzegovinian sancakbey. ${ }^{47}$ The harnessing of the Montenegrins seemed an impossible task. From the 1670 s on they constantly raided Dubrovnik territory, plunders tended to escalate, and finally peaked in the devastating pillage of the Republic in $1806 .{ }^{48}$

Good relations with emins, Ottoman customs officials posted near Dubrovnik border and in Dubrovnik itself, were essential for Ragusan trade. According to the hitherto traced data, Cafer, emin in Herceg Novi, was the first to fall victim of the Ragusan resolute policy. In 1523 Süleyman the Magnificent (1520-1566) increased

44 DA, 7/2.1, Sultans'documents, vol. 35, no. 1387; vol. 53, no. 1784; vol. 59, no. 1962; vol. 60, no. 1989.

45 Miović-Perić, Na razmedu, 209-265.

46 Let. Lev. vol. 67, ff. 94, 94v.

47 SAD, Miscellanea, $18^{\text {th }}$ century, vol. F XII/1, no. 5. DA, $18^{\text {th }}$ century, vol. 3346, no. 48, 50; vol. 3402, no. 35e. Acta Turc. vol. B 130, no. 73.

48 Vesna Čučić, Republic of Dubrovnik: Final Crisis (Chicago: CroLibertas Publishers, 2014), 133164. 
the customs duty for the Ragusans, while the Porte sent emin Cafer to Herceg Novi to make sure that the sultan's order was being carried out. By the end of the same year the sultan had already withdrawn his decision on the customs increment, but it had little impact on the deteriorated relations between Cafer and the Ragusans. According to Ragusan testimonies, his conduct towards merchants was harsh and offensive, their clothes were most thoroughly checked, they were delayed, their goods confiscated, and they were even detained. Thus in August 1525, at a secret session of the Senate, it was decided to "take steps against the life of emin Cafer". In the summer of 1526 "the post of the late emin Cafer" was filled by emin Korkut. ${ }^{49}$

Ragusan trade was also impeded by Mahmud, emin in Ledenice. As some Ragusan merchants were his debtors, late in 1558 he stopped a Ragusan caravan and confiscated all money. He acted contrary to the Ragusan abdname, which clearly stated that the debts of the Ragusan merchants may not be collected from their fellow-citizens..$^{50}$ Although at the Porte Mahmud was masterly defended by his son Mehmed, Ragusan ambassadors managed to petition a ferman to the sancakbey of Herzegovina and kadı of Herceg Novi to have Mahmud punished and make him return the money. However, they refused to do so. In their petitions against Mahmud, the Ragusans then turned to the kadıs of Novi Pazar, Foča and Istanbul. In the meantime, as Mahmud's witness the notorious blind Pavao, Ragusan enemy, appeared at the Porte. Pavao was a Ragusan whom Dubrovnik court accused of theft and rape and sentenced to blinding. Upon the execution of punishment, Pavao left the Republic, and in the Ottoman Empire claimed to be an Ottoman subject, which placed him beyond the jurisdiction of the Dubrovnik court of law. He testified before the Grand Vizier Rüstem Pasha. The latter was inclined towards the Republic of Dubrovnik, Ragusan ambassadors gave him 1,500 ducats, and introduced him to the truth about Pavao and Mahmud. That is why he paid little attention to the testimony of the blind Pavao, and ordered that Mahmud emin be called to testify in Istanbul.

As might have been expected, Ragusans plotted their own actions aimed at the elimination of Pavao and Mahmud. They engaged an expert in poisoning from Verona, dispatched him to Istanbul to poison Pavao, and at the same time offered 300 ducats and poison to the dizdar of Blagaj to wipe Mahmud out from "the book of the living". By the autumn of 1560 there was no trace of Pavao, which could mean that the poisoner had done his job as agreed. Mahmud, however, was arrested in Istanbul. He was sentenced, and then transferred to Cairo. ${ }^{51}$

49 Toma Popović, Turska i Dubrovnik u XVI veku (Beograd: Srpska književna zadruga, 1973), 132. Šndrica, "Poisons and Poisoning in the Republic of Dubrovnik," 27.

50 Ivan Božić, Dubrovnik i Turska u XIV i XV veku (Beograd: SAN, 1952), 229. Nicolaas Hendrik Biegman, The Turco-Ragusan Relationship (The Hague - Paris: Mouton, 1967), 58.

51 Acta Turc. no. 4181, 4299, 4483, 4510, 4512, 4546, 4567. Popović, Turska i Dubrovnik u XVI veku, 227-232. Šundrica, "Poisons and Poisoning in the Republic of Dubrovnik," 27. 
The so-called "emin of the Ragusan scala" was an Ottoman official who in the Dubrovnik suburb of Ploče collected customs from the Ottoman and foreign merchants. From the 1640s he lived in the tenth lazaretto of the newly-constructed Lazaretto at Ploče. Ragusan authorities liked to stress that the emins at Ploče were unofficial Ottoman consuls, as it was truly the case. Ottoman subjects arrived in the Dubrovnik area daily, to trade and do business with the Ragusans, they acted as debtors and creditors, or sought medical aid. Whatever was the purpose of their visit, they needed various documents, certificates, reports to be issued by emin. Emin also acted as an investigator and witness against Ottoman offenders, assaulters and robbers of Ragusan property. He was authorised to apprehend an Otoman offender and detain him in his lazaretto, interrogate him and write a report, after which Ottoman soldiers would escort the culprit to be trialed before the kadi. Emin was versed in settling thorny issues between Ottoman and Ragusan subjects, and by doing so reduced potential danger of the escalation of conflict and revenge. The Ragusans found it of utmost significance for the emin to supervise and keep under control the Ottoman subjects arriving at Ploče, and particularly in the Lazaretto.

Emins were most commonly recruited among the local men of Bosnia and Herzegovina, who were familiar with Dubrovnik and who could easily communicate with its citizens. From the early eighteenth century on, two emins were usually based at Ploče, in addition to a scribe and servant. ${ }^{52}$

Emin's term of office varied between six months and a year, which implies that Ploče witnessed great many of them. Some of them represented a serious threat to the Republic. Emin Süleyman Agha from 1643 was reputed for his scandals which made the merchants' life very difficult. Apparently, he crossed the line when he incited a group of Vlachs, some two to three hundred according to Ragusan testimonies, to throw stones at Ragusan soldiers at the city gates, whereby their commander was injured to death. Ragusan authorities amassed an impressive number of kadı reports, ${ }^{53}$ while the Herzegovnian sancakbey had Süleyman Agha immediately dismissed, ${ }^{54}$ and thus, most probably, saved his life.

Posted at the Ploče Lazaretto in 1649 was emin Mehmed Agha, for whom the Ragusans claimed collaborated with the Venetians over daily meals. Their goal was to destroy the trade via Dubrovnik port, in which the mentioned emin played such a prominent role that the Venetian captain of the Gulf presented him personally

2 Vesna Miović, "Life in the Quarantine: Lazaretto at Ploče During the Republic," in Lazaretto in Dubrovnik. Beginning of the Quarantine Regulation in Europe, ed. Ante Milošević (Dubrovnik: Institute for Restoration of Dubrovnik, 2018), 23-27.

53 Acta Turc. vol. C 6, no. 56, 57; vol. C 8, no. 1, 4, 6, 8, 10. Miović, "Life in the Quarantine," 25.

$54 D A, 7 / 2.2$, Buyuruldus, no. 2. For the deposition of emin to be fully legal, both the sancakbey and the Ragusans needed a ferman, which was issued one month later $(D A, 7 / 2.1$, Sultans' documents, vol. 20, no. 984, 985. Miović, "Life in the Quarantine," 35, 36). 
with a horse. One day, Ragusans claimed, Mehmed Agha simply took off from the Lazaretto, fled from the Republic, left the merchants without supervision and started spreading "diabolic fabrications" about his departure, apparently, he was to be murdered by the Dubrovnik authorities. "Diabolic fabrications" turned out to be true, because on the agenda of the secret session of the Senate held some time around his flight was a proposal "to eliminate Mehmed Agha, emin at Ploče". The proposal was denied, ${ }^{55}$ yet it may have easily reached emin's ears, intentionally and with forethought.

Ragusan authorities were particularly vigilant when Ottoman subjects employed in Dubrovnik were concerned. They included the so-called hocas, teachers hired to teach the basics of Ottoman language to future dragomans, recruited among young Ragusans.

In early June 1644, the Ragusans delivered the body of hoca Mustafa to emin Fazli Agha Šabanović. According to one document, he was a scribe, which could easily mean that he had been in Dubrovnik before and worked as emin's assistant. A part of the funeral rite was performed at Ploče, where Mustafa's body was washed, and where the imam and muezzin said the usual prayers. Eight men carried Mustafa to the Ottoman Carina (Ledenice), where a grave was dug. The poor were given money for his soul, prayers were said and halva distributed according to custom. All this was paid by the Ragusan authorities, while emin Fazli Agha issued them a certificate which, among other things, stated that Mustafa died by God's will. The fact that the Ragusans covered the funeral costs may be interpreted as a decent and human gesture towards a man they knew well. Yet, it proved otherwise. Fine manners were actually a guise for a dark story of which emin Fazli Agha did not even dream. Mustafa was poisoned as decided on a secret session of the Senate, "on the grounds presented against him in the process conducted at the Minor Council". Poison was prepared by surgeon Pavao, son of Andrija, for a fee of 50 perpers. ${ }^{56}$ As to why Mustafa was poisoned has not been established, his spying activity remains among the likely assumptions.

\section{CONCLUSION}

Ottoman sultans pledged to protect the Republic of Dubrovnik and its subjects from any kind of threat or violence on behalf of Ottoman dignitaries, officials or any other person of the Empire. In practice, however, due mostly to the crumbling hierarchy of the Ottoman government, the situation did not develop as agreed. Given the circumstances, Ragusans developed methods of legal and secret actions.

55 Let. Lev. sv. 50, f. 23. Secr. Rog. vol. 4, f. 194.

56 Acta Turc. vol. 143, no. 4. Secr. Rog. vol. 4, ff. 142, 143, 143v. Šundrica, "Poisons and Poisoning in the Republic of Dubrovnik," 31. 
They obtained favourable kad1 reports and documents, buyuruldus of Bosnian beylerbeys and Herzegovinian sancakbeys, as well as sultan's fermans. They paid for the issue of these reports and documents, just as much as they were prepared to pay for their implementation. The process was time-consuming and costly with an unknown result. To have things under closer control, the Ragusans at the same time deliberated secretly on how to eliminate undesirable individuals, poisoning being one of the commonest methods. It is not known whether they ever deliberated on poisoning any of the Bosnian beylerbeys or Herzegovinian sancakbeys, leaving us to believe that such radical steps remained beyond their consideration. Undesirable imperial dignitaries they removed by lobbying at the Porte, always together with the traditionally inclined dignitaries of Bosnian descent, and also by giving money and other gifts, all within a carefully orchestrated "performance". Discreet gifts of hundreds and thousands of ducats over the centuries were to remind the Ottomans of how loyal, helpless and harmless their Ragusan tributaries were. Ottoman protective instincts towards such a fragile tributary were further roused by a convincing performance spiced with tears. Behind a masque of helplessness, through bribe, poison and good connections at the Ottoman courts from Bosnia and Herzegovina to Istanbul, lay the power of this tiny state.

\section{BIBLIOGRAPHY}

\section{UNPUBLISHED ARCHIVAL SOURCES}

State Archive in Dubrovnik (SAD)

Acta Consilii Rogatorum

Acta Turcarum (Acta Turc.)

Diplomata et Acta (DA)

Lettere di Levante (Let. Lev.)

Secreta Rogatorum (Secr. Rog.)

\section{LITERATURE}

Biegman, Nicolaas Hendrik. The Turco-Ragusan Relationship (The Hague - Paris: Mouton, 1967).

Božić, Ivan. Dubrovnik i Turska u XIV i XV veku (Beograd: SAN, 1952).

Čučić, Vesna. Republic of Dubrovnik: Final Crisis (Chicago: CroLibertas Publishers, 2014) 
Hrabak, Bogumil. “'Zlići' iz Herceg-Novog i zulumćarenje na uštrb dubrovačke trgovine 1600-1667. godine." Boka 12 (1980), 81-119.

Lazzarini, Isabella. "Argument and Emotion in Italian Diplomacy in the Early Fifteenth Century: the Case of Rinaldo degli Albizzi (Florence, 13991439)," in: The Languages of Political Society, ed. A. Gamberini, J.-P. Genet (Roma: Viella, 2011), 339-369.

Miović, Vesna. Dubrovačka diplomacija u Istambulu (Zagreb - Dubrovnik: HAZU Zavod za povijesne znanosti u Dubrovniku, 2003).

Miović, Vesna. "Beylerbey of Bosnia and Sancakbey of Herzegovina in the Diplomacy of the Dubrovnik Republic." Dubrovnik Annals 9 (2005):37-69.

Miović, Vesna. "Diplomatic Relations Between the Ottoman Empire and the Republic of Dubrovnik," in: The European Tributary States of the Ottoman Empire in the Sixteenth and Seventeenth Centuries, ed. Gábor Kármán, Lovro Kunčević (Leiden-Boston: Brill, 2013), 187-208.

Miović, Vesna. "Life in the Quarantine: Lazaretto at Ploče During the Republic," in Lazaretto in Dubrovnik. Beginning of the Quarantine Regulation in Europe, ed. Ante Milošević (Dubrovnik: Institute for Restoration of Dubrovnik, 2018), 13-49.

Miović-Perić, Vesna. Na razmedu; osmansko-dubrovačka granica 1667-1806 (Dubrovnik: Zavod za povijesne znanosti HAZU u Dubrovniku, 1997).

Popović, Toma. Turska i Dubrovnik u XVI veku (Beograd: Srpska književna zadruga, 1973).

Preto, Paolo. I servizi segreti di Venezia (Milano: Il Saggiatore, 1994).

Samardžić, Radovan. "Odnosi Bosne i Dubrovnika od 1656 do 1662." Godišnjak Istoriskog drustva Bosne i Hercegovine 8 (1956): 87-173.

Samardžić, Radovan. Veliki vek Dubrovnika (Beograd: Prosveta, 1983)

Šundrica, Zdravko. "Tajanstvena kutija iz arhiva Dubrovačke Republike." Dubrovački vjesnik, April 11, 1958, 7; April 18, 1958, 7; May 9, 1958, 5; May 17, 1958, 5; May 24, 1958, 7.

Sundrica, Zdravko. "Poisons and Poisoning in the Republic of Dubrovnik." Dubrovnik Annals 4 (2000): 7-79.

Vinaver, Vuk. "Bosna i Dubrovnik 1595-1645." Godišnjak Društva istoričara Bosne i Hercegovine 13 (1962: 199-232.

de Vivo, Filippo. "Archives of Speech: Recording Diplomats Negotiation in Late Medieval and Early Modern Italy." European History Quarterly 46/3 (2016): 519-544.

Vučetić, Antun. Lokrum i odnošaji Dubrovnika sa Mletcima u XVII vieku iz izvještaja poslanika M. Sorga (Split: Štamparija A. Zannoni, M. Snidarčić, 1889). 
Vučetić, Antun. Dubrovnik za Kandijskog rata 1645-1669 iz dopisivanja Republike s M. Sorgom-Bobalijem (Dubrovnik: published by author, 1896).

Zovko, Valentina. "The First Ambassadors from Dubrovnik at the Sublime Porte (1430/31)," in: Turkey \& Romania; A History of Partnership and Collaboration in the Balkans, ed. Florentina Nitu, Cosmin Ionita, Metin Ünver, Özgür Kolçak, Hacer Topaktaş (Istanbul: Türk Dünyası Belediyeler Birliği, 2016), 37-68. 